груп під наглядом викладача, або для самостійних занять після ретельного вивчення техніки виконання вправ.

\title{
Література:
}

1. Холодов Ж.К. Теория и методика физической культуры и спорта / Ж.К. Холодов, В.С. Кузнецов. - 13-е изд., испр. и доп. Москва: Издательский центр «Академия», 2016. - 480 с.

2. Щорічна доповідь про стан здоров'я населення, санітарноепідемічну ситуацію та результати діяльності системи охорони здоров’я України. 2017 рік. - Київ: МОЗ України, ДУ «УІСД МО3 України», 2017. - $516 \mathrm{c}$.

3. O TRX. Официальный сайт TRX в Украине [Електронний pecypc] - Режим доступу до ресурсу:

URL:http//www.trxtraining.com.ua/o-trx/.

\section{DOI https://doi.org/10.30525/978-9934-26-044-5-14}

\section{ГЕНДЕРНІ ОСОБЛИВОСТІ МОТИВАЦІЇ ДО ЗАНЯТЬ ОЗДОРОВЧО-РЕКРЕАЦІЙНОЮ АКТИВНІСТЮ СТУДЕНТСЬКОЇ МОЛОДІ}

\author{
Ковтун А. О. \\ кандидат біологічних наук, доиент, \\ дочент кафедри теорії і методики фізичного виховання \\ Придніпровська державна академія фізичної культури і спорту \\ м. Дніпро, Украӥна
}

Як зазначають науковці Дутчак М., Андрєєва О., Благій О. [1, 4], оздоровчо-рекреаційна рухова активність - це спеціально-організована рухова активність належного обсягу та оптимальної інтенсивності, форми та види якої добровільно обираються та реалізуються людиною під час дозвілля 3 метою відновлення працездатності, зменшення ризику розвитку хронічних захворювань та ведення здорового способу життя. Оздоровчо-рекреаційні заняття стають дедалі популярнішими серед студентської молоді завдяки тому, що все більше молодих людей усвідомлюють їх оздоровче значення [2,6]. Сучасні форми та зміст рекреаційних занять доволі різноманітні. При цьому вибір видів 
фізичної активності зумовлений не лише їх популярністю, а й потребами та інтересами людини в залежності від іiі гендерної ідентичності [3, 5].

Питання про можливі гендерні відмінності студентів при заняттях фізичною культурою розглядали вчені Т. Круцевич, О. Марченко, Г. Безверхня, О. Біліченко та інші $[2,3,7,8]$. Їх наукова робота присвячена визначенню шляхів підвищення ефктивності занять 3 фізичного виховання у закладах вищої освіти. Проте проблема дослідження мотивації студентів до занять оздоровчо-рекреаційною руховою активністю 3 урахуванням гендерних особливостей залишається актуальною.

Метою дослідження було виявити гендерні особливості мотивації до занять оздоровчо-рекреаційною руховою активністю студентів. В дослідженні прийняли участь студенти I-II курсу основного відділення (67 юнаків та 65 дівчат) Дніпровського національного університету імені Олеся Гончара. Всі досліджувані студенти у вільний час за бажанням відвідували фізкультурно-оздоровчі та спортивні секції. Для вирішення поставлених завдань були використані такі методи дослідження: аналіз літературних джерел, педагогічне спостереження, педагогічний експеримент, анкетування, методи математичної статистики.

У системі цінностей кожної особистості, тим більше молодої людини, яка щойно розпочинає самостійне життя, можна вирізнити домінантні цінності. Це пріоритетне ядро ціннісної ієрархії. Цінності виступають фундаментом, мотиваційною основою поведінки будь-якої особистості. Ми провели порівняльний аналіз ціннісних орієнтацій юнаків та дівчат, які навчаються у закладах вищої освіти. Виявилось, що для юнаків найважливішими цінностями були здоров'я та свобода (по 24\% студентів), сім'я (20\%), матеріальне благополуччя (16\%), якісна освіта (8\%) та спілкування з цікавими людьми (8\%). Це вказує на те, що здоров'я для юнаків не $\epsilon$ абсолютною домінантою в індивідуальній ієрархії їх цінностей. Для 72\% дівчат найважливішою цінністю було здоров'я, для $24 \%$ дівчат - сім'я, для $4 \%$ - свобода, тобто для дівчат навпаки відзначається висока значущість здоров'я в індивідуальній ієрархії цінностей, що можна трактувати як більш уважне ставлення до власного здоров'я.

Порівняльний аналіз відповідей студентів на питання анкети дозволив виявити пріоритетні мотиви юнаків та дівчат, які спонукають ї до занять оздоровчо-рекреаційною руховою активністю (рис. 1). Для юнаків основним мотивом було досягнення гармонійної тілобудови (80\%). На другому місці розташувалися мотиви підвищення фізичної 
підготовленості (70\%) та покращення здоров'я (70\%), а потім реєструвався мотив активного відпочинку (25\%). Пріоритетна мотивація до красивої зовнішності у юнаків може бути пов'язана 3 бажанням подобатися дівчатам та досягати успіху в тих видах діяльності, які залежать від зовнішнього вигляду. Проте студенти також розуміють значення фізичної культури і спорту у збереженні свого фізичного і психічного здоров'я засобами фізичного виховання. Звертає на себе увагу, що у попередніх дослідженнях науковців головним мотивом до занять фізичною культурою у юнаків був лише мотив підвищення фізичної підготовленості, тобто у нашому дослідженні була виявлена зміна традиційно домінуючого мотиву у юнаків.

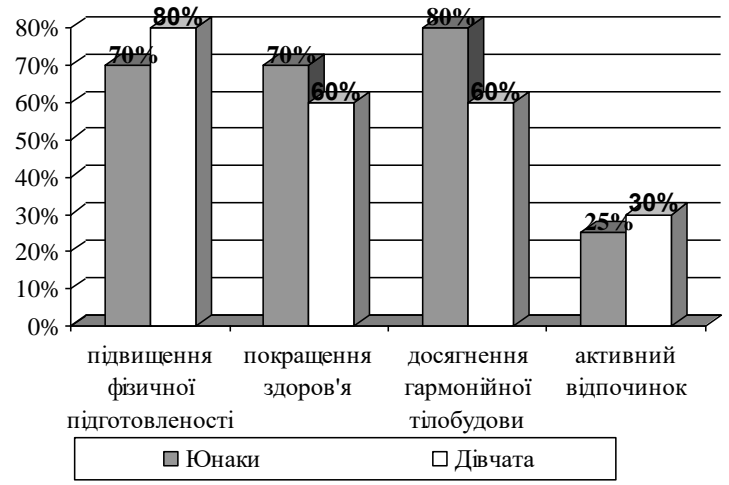

\section{Рис. 1. Пріоритетні мотиви до занять фізичною культурою і спортом юнаків та дівчат, що відвідують спортивні секції}

Для дівчат, що відвідують оздоровчо-рекреаційні заняття, головним виявився мотив підвищення фізичної підготовленості (80\%). На другому місці розташувалися мотиви покращення здоров'я (60\%) та досягнення гармонійної тілобудови (60\%). На третьому місці у дівчат знаходився мотив активного відпочинку (30\%). На наш погляд, для дівчат в сучасних умовах гендерної рівності фізична підготовленість має велике значення для професійного зростання і успіху у житті. При цьому мотивація до міцного здоров'я та красивої зовнішності у дівчат також присутня і пояснюється необхідністю успішного виконання жінками своїх соціальних функцій, зокрема громадянських, трудових та сімейних. Проте ми знову зареєстрували зміну головного мотиву до 
занять фізичною культурою у дівчат, оскільки раніше таким мотивом був мотив досягнення гармонійної тілобудови.

Особливості прояву мотивації до занять фізичними вправами у юнаків і дівчат пов'язані з різними інтересами у виборі видів рухової активності. Найбільш популярними у юнаків були легка атлетика (65\%), спортивні ігри (40\%), одноборства (35\%), спортивна гімнастика (35\%), фітнес (30\%), плавання (25\%), туризм (20\%) та танці $(10 \%)$. Дівчата надали перевагу таким видам рухової активності, як гімнастика (60\%), спортивні ігри (40\%), фітнес (40\%), танці (40\%), одноборства $(40 \%)$, легка атлетика (30\%), плавання (20\%) та туризм (20\%). Більшість юнаків та дівчат обирали по декілька видів рухової активності. Звертає на себе увагу, що найбільшу популярність у юнаків, які брали участь у нашому опитуванні, отримала легка атлетика. В той же час у дівчат найбільшою популярністю користувалася гімнастика. При цьому аналогічний інтерес за відсотковим значенням як у юнаків, так і у дівчат мали спортивні ігри, одноборства, фітнес, плавання та туризм, що свідчить про сучасні тенденції до гендерної рівності.

Аналіз результатів дослідження показав, що при формуванні сучасних підходів до організації занять оздоровчо-рекреаційною руховою активністю необхідно враховувати сучасні гендерні особливості студентської молоді, що дозволить виявити та використати скриті можливості процесу фізичного виховання для розвитку i самореалізації кожного студента.

\section{Література:}

1. Андрєєва О., Дутчак М., Благій О. Теоретичні засади оздоровчорекреаційної рухової активності різних груп населення. Теорія іметодика фізичного виховання $i$ спорту. 2020. № 2. С. 59-66. DOI: $10.32652 /$ tmfvs.2020.2.59-66

2. Безверхня Г.В., Цибульська В.В., Гончар Г.І. Формування мотивації до занять фізичною культурою і спортом школярів та студентів : монографія. Умань : ВПЦ «Візаві», 2016. 223 с.

3. Биличенко Е.А. Гендерные особенности формирования мотивации к занятиям физическим воспитанием у студентов : дис... канд. наук по физ. восп. и спорту : 24.00.02 / Днепропетровский государственный институт физической культуры и спорта. Днепропетровск, 2014. 292 с.

4. Дутчак M, Баженков $Є$. Теоретичний аналіз дефініції «оздоровчо-рекреаційна рухова активність». Спортивна наука Украӥни. 2015; № 5. C. 56-63. URL: http://nbuv.gov.ua/UJRN/SNU_2015_5_11 (дата звернення: 15.02.2021). 
5. Ковтун А., Татарченко Л. Гендерні особливості мотивації студентів до занять фізичною культурою і спортом. Спортивний вісник Придніпров'я. 2018. № 2. С. 44-49.

6. Круцевич Т.Ю., Безверхня Г.В. Рекреація у фізичному вихованні різних груп населення. Київ: Олімпійська л-ра, 2010. 200 с.

7. Круцевич Т.Ю., Захарченко М.О., Марченко О.Ю. Врахування гендерного підходу в процесі занять з фізичного виховання учнівської молоді. Молодий вчений. 2017. № 3.1 (43.1). С. 180-183.

8. Круцевич Т., Марченко О., Імас Т. Проблема гендеру у фізичному вихованні дітей, підлітків і молоді. Фізичне виховання, спорт і культура здоров'я у сучасному суспільстві. 2015. № 3(31). C. 144-146.

\title{
DOI https://doi.org/10.30525/978-9934-26-044-5-15
}

\section{ОЗДОРОВЧЕ ЗНАЧЕННЯ ПЛАВАННЯ ДЛЯ МАЛЮКІВ РАННЬОГО ВІКУ}

\author{
Козуб С. В. \\ методист, керівник фізичного виховання
}

ВСП «Фаховий коледж харчових технологій та підприємництвва Дніпровського державного технічного університету»

\author{
Пойда В. Ю. \\ студентка II курсу
}

ВСП «Фаховий коледж харчових технологій та підприємництва Дніпровського державного технічного університету» м. Кам'янське, Дніпропетровська область, Украӥна

Актуальність. Фізичне виховання здійснюється у тісному зв'язку з розумовим, моральним, естетичним вихованням, займає одне 3 найважливіших місць у підготовці дітей до самостійного життя, виховує рухову грамотність та особистісні якості, сприяє соціальній адаптації та інтеграції в суспільство. Плавання в системі фізичного виховання визначається перед усім його важливим оздоровчим значенням і доступністю для людей різного віку.

Плавання - це ще один урок життя, який потрібно пройти кожному. Немає людей, що не можуть навчитися плавати, потрібно лише знайти правильну методику. Плавання - дуже корисне заняття, 66 